\title{
Navegando sobre lugares. Um ensaio da percepção do ambiente através de uma etnografía arqueológica da pesca
}

\author{
SAILING OVER PLACES. AN ESSAY ON THE PERCEPTION OF THE ENVIRONMENT \\ THROUGH AN ARCHAEOLOGICAL ETHNOGRAPHY OF FISHERIES
}

\section{NAVEGANDO POR LUGARES. UN ENSAYO SOBRE LA PERCEPCIÓN DEL MEDIO AMBIENTE A TRAVÉS DE UNA ETNOGRAFÍA ARQUEOLÓGICA DE LA PESCA}

\author{
Lucas Antonio da Silva*1 \\ las.arqueo@gmail.com \\ Recibido: 06/5/2020 Aceptado: 02/8/2020
}

Resumo

0 presente texto é fruto de uma etnografia arqueológica conduzida desde o ano de 2010, na comunidade de pescadores da Barra do João Pedro, Rio Grande do Sul. Através de uma observação participante engajada, na qual experimentei diversas práticas de pesca, observei a importância do ambiente para a vida da comunidade e para a construção de minhas narrativas. A partir disso, proponho no presente texto, uma imersão no ambiente e nas percepções que vivenciei ao longo dos deslocamentos realizados com os pescadores. Para tanto, utilizei uma narrativa etnográfica detalhada do ambiente em seu emaranhamento, destacando os lugares, as histórias contadas e os seres envolvidos nos fenômenos observados.

Palavras-chave: Ambiente, Percepções, Pescadores, Narrativa

\begin{abstract}
This text is the result of an archaeological ethnography conducted since 2010, in the fishing community of Barra do João Pedro, Rio Grande do Sul. Through an engaged participant observation, in which I tried out different fishing practices, I observed the importance of environment for the life of the community and for the construction of my narratives. From this, I propose in the present text, an immersion in the environment and in the perceptions that I experienced during the displacements made with the fishermen. For that, I used a detailed ethnographic narrative of the environment in its entanglement, highlighting the places, the stories told and the beings involved in the observed phenomena.
\end{abstract}

Keywords: Perceptions, Fishermen, Narrative

\section{Resumen}

Este texto es el resultado de una etnografía arqueológica realizada desde 2010, en la comunidad pesquera de Barra do João Pedro, Rio Grande do Sul. A través de una observación participante comprometida, en la que probé diferentes prácticas de pesca, observé la importancia del medio ambiente para la vida de la comunidad y para la construcción de mis narrativas. A partir de esto, propongo en el presente texto, una inmersión en el entorno y en las percepciones que experimenté durante los desplazamientos realizados con los pescadores. Para eso, utilicé una narrativa etnográfica detallada del entorno en su enredo,

\footnotetext{
1 * Pontifícia Universidade Católica do Rio Grande do Sul.
}

Tekoporá ${ }^{\circledR}$. Centro Universitario de la Región Este. Universidad de la República (C) da Silva (2020)

Este es un artículo de Acceso Abierto distribuido bajo licencia Creative Commons (CC BY NC 4.0) 
destacando los lugares, las historias contadas y los seres involucrados en los fenómenos observados.

Palabras clave: Ambiente, Percepciones, Pescadores, Narrativas

\title{
Introdução
}

\begin{abstract}
"Mas o que é a aura, de fato? Uma trama peculiar de espaço e tempo: a aparição única de uma distância, por mais próxima que ela esteja. Observar calmamente, em uma tarde de verão, uma paisagem montanhosa no horizonte, ou um ramo que joga sua sombra sobre o observador - é isso que significa respirar a aura dessas montanhas, desse ramo" (Walter Benjamin, 2013, p. 59)
\end{abstract}

Este texto nasce das experiências de uma etnografia arqueológica com pescadores do litoral norte do Rio Grande do Sul. Desde que iniciei este percurso de pesquisa no ano de 2010, aprendi muitas lições sobre a pesca e conheci muitos lugares com a mediação dos pescadores. Foram inúmeros deslocamentos, passando por rios, lagoas, banhados, capões de mato, campos, etc. Entretanto, ao desenvolver a narrativa das relações materiais, percebi que uma parte significativa do trabalho etnográfico poderia também se tornar uma construção textual: as percepções do ambiente. Uma tentativa de descrever as percepções que tive do ambiente a partir das experiências e observações dos lugares junto aos pescadores.

Entre os pescadores da comunidade existem alguns aspectos comuns, tais como, a utilização de pequenas embarcações, o mesmo tipo de objetos de pesca, a divisão do trabalho por gênero e lugar - mulheres lidam com as atividades de pesca em terra, já os homens transitam entre terra e água - e, por fim, o domínio das práticas de navegação. Entretanto, apesar de trabalhar com muitos pescadores, o principal interlocutor da pesquisa foi o Velho lobo da água doce. Como é um dos poucos pescadores da comunidade que se dedica exclusivamente a pesca, o Velho lobo é reconhecido como uma referência nos assuntos que envolvem a atividade pesqueira. Esse reconhecimento, que advém de seu amplo conhecimento da região e das práticas cotidianas, se verifica, por exemplo, nas inúmeras vezes em que os pescadores mais jovens buscam conselhos e sugestões para a pesca, demonstrando a importância do Velho lobo como um veterano da região. Foi principalmente através dos ensinamentos e mediações proporcionadas pelo Velho lobo que construí parte das percepções do ambiente descritas na narrativa que segue.

Além de percorrer o ambiente e experimentar uma gama considerável de práticas de pesca, entendo ser necessário mencionar a contribuição descritiva de Edgard Roquette-Pinto (1962[1906]) como uma inspiração para a construção deste texto. No ano de 1906, RoquettePinto realizou uma expedição científica ao litoral norte do Rio Grande do Sul. Seu objetivo era verificar e descrever as condições dos sítios arqueológicos do tipo sambaquis da região, especialmente no município de Torres. Ao longo de sua viagem pelo litoral, conduzida através dos rios e lagoas da região com auxílio dos pescadores locais, o autor descreveu suas percepções do ambiente e relatou as histórias e momentos pelos quais passou. Sua narrativa possui um teor poético, sem o abandono do rigor científico, e relata com precisão inúmeros lugares e características que encontrei no mesmo ambiente mais de um século depois de sua viagem ao litoral norte do Rio Grande do Sul. 
Por um lado, essa semelhança e inspiração no relato do autor deriva da preservação de alguns dos lugares pelos quais ele passou, que permaneceram, até então, com certo isolamento da ação humana. Por outro, se aproximam as condições nas quais conhecemos os mesmos lugares, já que Roquette-Pinto navegou por grande parte da área na qual acompanhei os pescadores da Barra do João Pedro. Portanto, para evidenciar a forte inspiração no trabalho do autor, destaco um pequeno trecho de sua descrição:

“Depois de certa hora foi preciso que remássemos firmes. À noitinha tínhamos chegado à Lagoa das Malvas, mais um formoso ela da cadeia de lagos do Rio Grande do Sul. Ela é regularmente circular e vai até as fraldas da Serra, para o lado do Ocidente. Atravessamo-la em meia hora, graças ao vento. Logo em seguida percorremos o rio do mesmo nome [o rio da Barra], ligação entre essa lagoa e a dos Quadros, ou Maquiné, a cuja barra chegamos à noite. A canoa tinha feito água; a nossa provisão de farinha foi por isso diminuída em alguns litros que se inutilizaram. Por informações do canoeiro soube que em certos anos tôda a região de banhados, desde o capão do Quirino até aqui, transformase em um só lago, por efeito da enchente." (Roquette-Pinto, 1906, p. 27)

Esse ato proposto por Roquette-Pinto de descrever sua percepção do ambiente que me inspirou a propor uma narrativa semelhante. A abordagem etnográfica de maior duração, pela qual sigo orientando minhas pesquisas, possibilitou um conflito com os lugares por meio da navegação e da experiência com os pescadores em suas práticas cotidianas.

Diante disso, o objetivo do texto é apresentar uma narrativa de minhas percepções do ambiente através da pesca embarcada. Considerando meu olhar de arqueólogo e as experiências ao longo dos lugares, pretendo expressar parte das vivências nem sempre relatadas em uma etnografia arqueológica. Para tanto, apresento a seguir alguns elementos teóricos que guiaram essas experiências e a construção da narrativa.

\section{Habitar e narrar}

Nessa trajetória de pesquisa etnográfica com os pescadores percorri caminhos teóricos diversos ao longo do tempo. Não cabe realizar uma retrospectiva de todo esse movimento, mas sim, destacar duas contribuições para a elaboração das narrativas mais recentes, principalmente a presente.

Na vasta produção teórica de Tim Ingold, a noção de ambiente como uma tessitura entre lugares, seres e materiais é o ponto inicial de sua contribuição. Com diferentes termos ambiente, ambiente-mundo ou atmosfera - o autor propõe que o lugar é o mundo que existe e assume um significado em relação a cada organismo, sendo assim, ele desenvolve com e ao longo de cada ser. 0 ambiente nunca é completo, pois são as vidas que se desenvolvem nele que o forjam, portanto, ele está sempre em descoberta e o mesmo vale para os organismos que nele habitam. Por fim, o autor destaca a diferença entre o conceito de ambiente e natureza, segundo ele, essa distinção se configura respectivamente em compreender nós mesmos como estando no mundo e estando fora dele, desse modo, a ideia de natureza nos retira do mundo e reforça as dicotomias do pensamento ocidental. Sendo assim, segundo Ingold (2013a, 2015) o ambiente é um mundo que continuamente se desdobra para seus habitantes, descrever ele é contar histórias que fluem, se misturam e se relacionam a todo momento.

0 ambiente, tal como afirma o autor, encontra-se em constante desdobramento para seus habitantes. Por isso, a perspectiva da habitação - dwelling perspective - proposta 
por Ingold $(2000,2015)$ é outro ponto chave para minha narrativa. Habitar é viver essa abertura e desdobramento constante do ambiente como fazem, por exemplo, os pescadores que se encontram imersos na tessitura do ambiente em suas práticas cotidianas. Navegar, capturar peixes, conhecer o clima e os ciclos sazonais das águas são práticas de engajamento no ambiente, isto é, se constituem através da percepção material dos lugares e fenômenos. Daí deriva a primeira parte da contribuição teórica de Ingold para a narrativa: a relação entre habitar o ambiente e percebê-lo. Ao longo destes dez anos de pesquisa minha proposta seguiu exatamente no sentido de habitar o mundo da pesca. Ainda que não o faça como um pescador, mas como um pesquisador, isso permitiu que eu constituísse minhas próprias experiências e percepções sobre os lugares de pesca.

A segunda contribuição teórica foi no modo de condução da etnografia e construção da narrativa. Seguindo a proposição de Ingold (2015), habitar implicou na estratégia principal de trabalho de campo, portanto, o engajamento prático no cotidiano das atividades pesqueiras foi fundamental na condução da observação. Além de participar das atividades como, remar, conduzir a embarcação, limpar os peixes, iscar espinhel e embarcar as redes, me dediquei a ouvir cuidadosamente as histórias que os pescadores contavam. Curiosamente, tal como irei relatar na narrativa sobre o ambiente, as histórias que eram contadas em seu próprio lugar me afetavam mais. Por exemplo, saber de uma grande pescaria realizada na lagoa em que nos encontrávamos pescando era, em certa medida, uma materialização da história. O lugar estava ali, o pescador, as redes, o barco e a água também, tornando aquele momento, certa experiência perceptiva da história por meio do ambiente e sua tessitura - lugar, os seres e os materiais.

A partir disso, passei a seguir a orientação proposta por Ingold (2012, 2013b, 2015) para deixar a experiência de engajamento fluir através da narrativa. Esse redimensionamento entre observação e participação, destacado pelo autor (Ingold, 2014) gerou algumas consequências para a narrativa, dentre elas, destaco a dificuldade em separar as percepções - quais eram propriamente minhas ou quais eram dos pescadores. Textualmente, essa diferenciação se tornou ainda mais difícil, principalmente quando, em meio a um deslocamento embarcado, não era possível fazer um registro escrito, ou quando dei prioridade à participação, ao invés da observação.

Destacada essa dificuldade de diferenciação busquei na contribuição de Christopher Tilley $(1994,2004)$ um caminho possível para construir a narrativa. Partindo de uma proposta fenomenológica, Tilley $(1994,2004)$ coloca que nossas percepções do ambiente - paisagem, para o autor - se realizam através da relação que estabelecemos com essa tessitura entre o lugar, seres e materiais. Portanto, a experiência de perceber algo está imersa nas relações tal como a construção da narrativa, isto é, muitas vezes não é possível desatar esse emaranhamento - para usar uma expressão de Ingold - que se estabeleceu, neste caso, na percepção dos fenômenos na pesca artesanal. Tilley $(1994,2004)$ e Ingold (2015) convergem que a alternativa para isso se dá pela descrição detalhada da percepção em seu contexto, evidenciando os pormenores das relações vivenciadas e os partícipes ao longo da experiência. Foi isso que Tilley (1994) chamou de arte da narrativa - art of narrative - e Ingold (2014) de arte de descrever - art of describing - como um procedimento de escrita que combinasse as experiências e contextos em um texto no qual pudessem emergir até mesmo os sentimentos do escritor/partícipe.

Diante disso, a proposta seguiu a abordagem descritiva das minhas experiências, reconhecendo que a mediação dos pescadores foi fundamental para a percepção dos fenômenos vivenciados. Entretanto, essa mediação não se tratou apenas do ato de me conduzir aos lugares, 
mas sim de contextualizá-los nas suas práticas de vida na pesca. Assim sendo, os pescadores são parte fundamental de minha percepção do seu ambiente.

\section{Um amplo olhar sobre o ambiente}

A Barra do João Pedro é uma pequena comunidade de pescadores, localizada no litoral norte do Rio Grande do Sul. Essa região foi profundamente afetada pelos avanços e recuos do nível do mar, ao longo de sua história geológica (Wagner, 2009). Essas transgressões e regressões marinhas moldaram a planície costeira, dando origem ao conjunto de lagoas, rios e

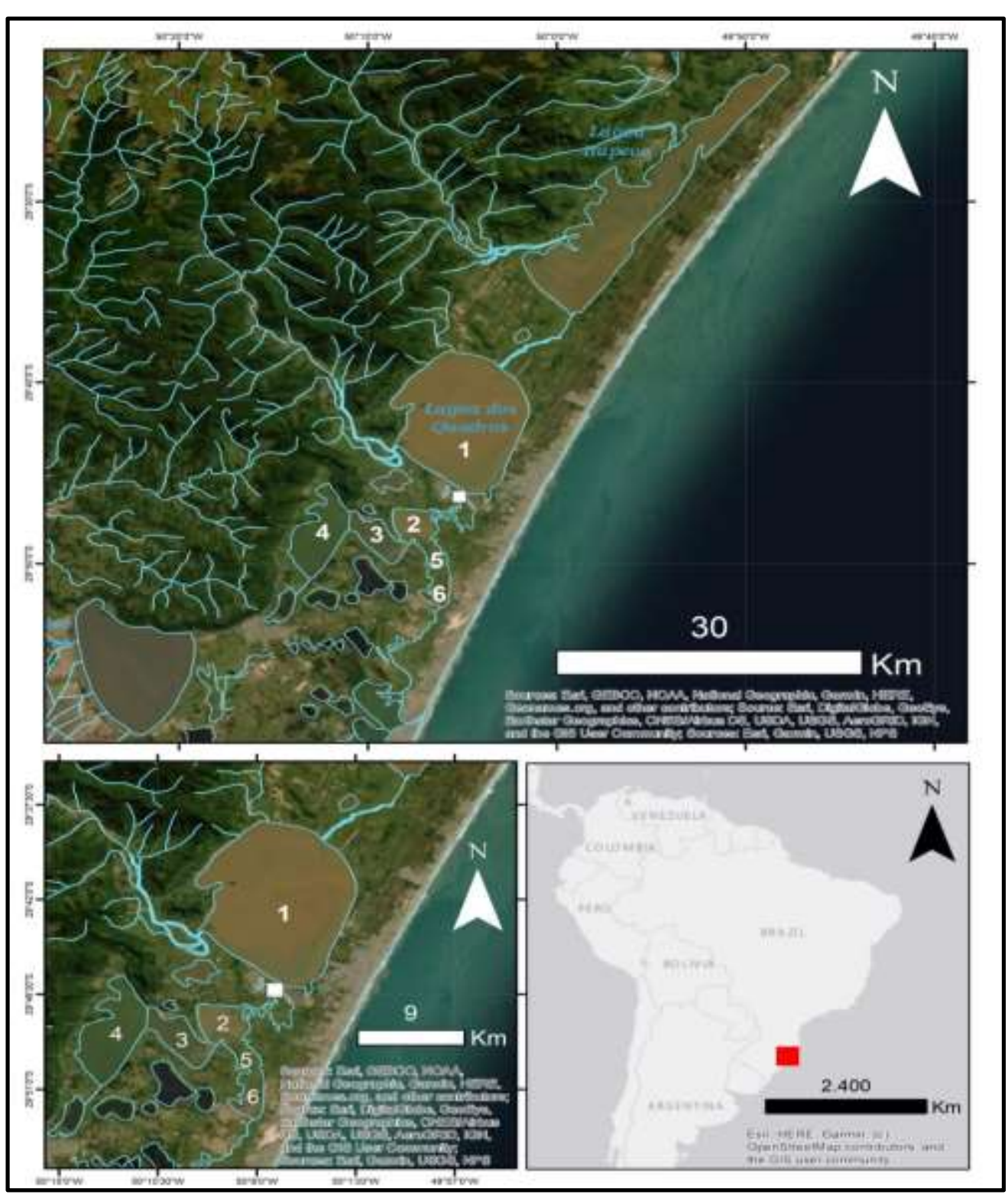

banhados que, atualmente, compõem a região. $\mathrm{Na}$ medida em que o mar foi recuando, parte dessa água salgada ficou reclusa nos locais mais baixos e, aos poucos, ela foi perdendo sua qualidade marinha e passou a adotar seu aspecto salobro tal como está hoje.

Figura 1. Mapa do litoral norte do RS com área de pesquisa. (1) lagoa dos Quadros; quadrado branco - comunidade e rio da Barra; (2) lagoa das Malvas, (3) do Palmital, (4) da Pinguela; (5) rio de Baixo; (6) lagoa do Passo. (Elaborado pelo autor). 
Essa história dos processos de formação da planície costeira do Rio Grande do Sul foi apresentada algumas vezes aos pescadores. Sempre com olhares desconfiados, algumas vezes surpresos, eles imediatamente buscavam em suas lembranças algum material que pudesse dar suporte, e certa veracidade, a esta história: "é por isso que tem esses casqueiros [sambaquis] aqui tão longe do mar?!” ou “o pessoal às vezes cava uns poços lá perto da serra e acha esses mesmos mariscos da beira da praia".

Desenhando uma linha reta que ligue a comunidade até o mar, atualmente, dista em torno de seis quilômetros da praia salgada. Os pescadores encontraram, na materialidade do seu dia a dia, o suporte para compreender essa história e, ao mesmo tempo, entender como as coisas do mar se encontram tão longe dele. A relação proposta pelos pescadores revela a possibilidade de explicar fenômenos que estão dispostos no mundo através dos materiais articulados aos seus lugares.

Tudo isso era a história que eu contava sobre o lugar para estes trabalhadores da pesca. Era uma narrativa com dados científicos bem articulados (mapas, ilustrações, tabelas), mas menos agradáveis que as contadas pelos pescadores ao longo de nossos deslocamentos na água, nas fogueiras dos acampamentos ou nos cafés da manhã. Não há datação radiocarbônica, fotografia ou mapa que comprove suas histórias, eles apenas afirmam "os antigos que diziam que o mar vinha até a serra, depois ele voltou". Essa frase tem um impacto grande, pois, ao ouvila, imediatamente os olhos são convidados a observar a serra, os banhados, as lagoas e os rios que se estendem diante do corpo.

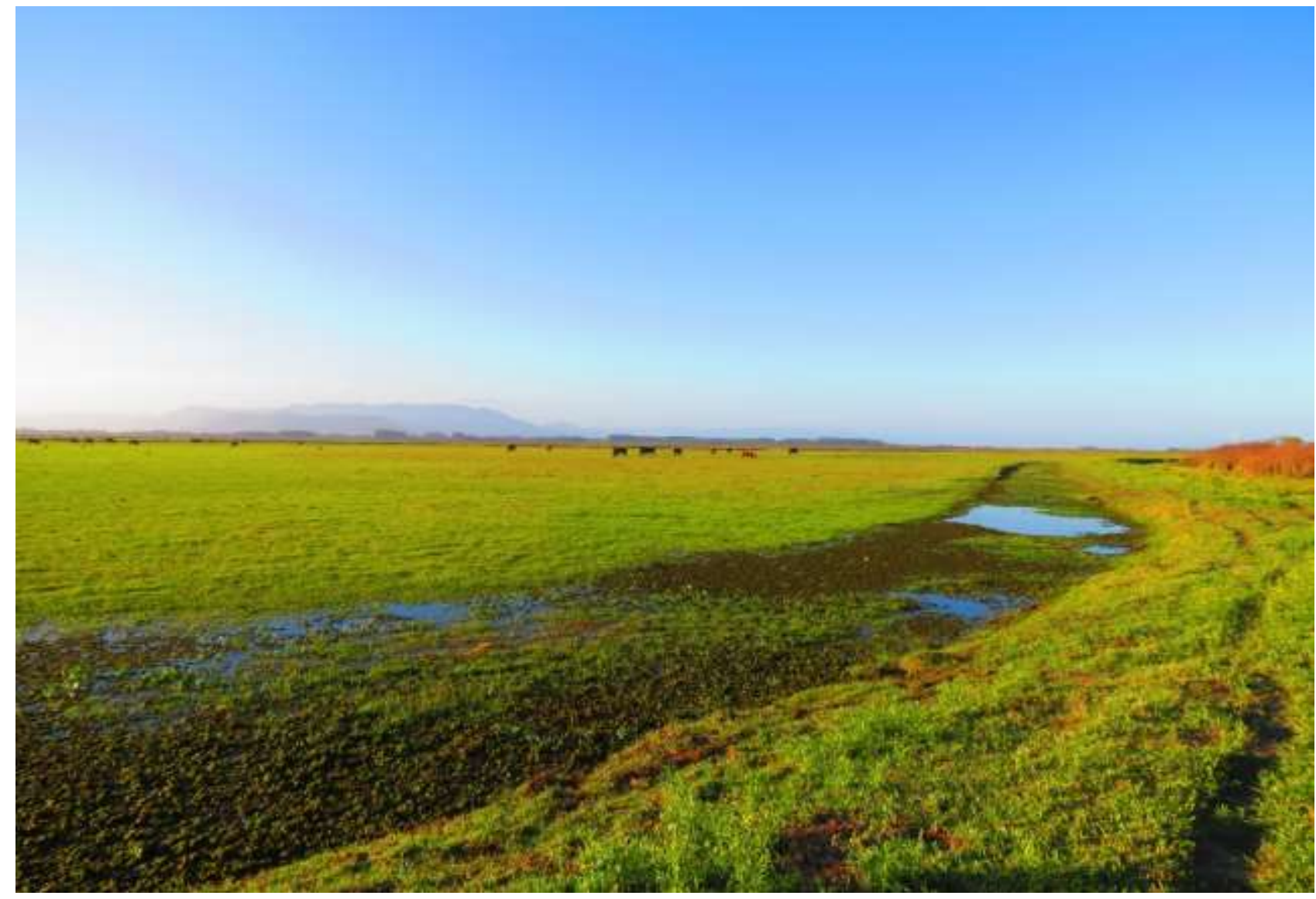

Figura 2. Campo e lomba próxima ao rio de Baixo (foto do autor, 09/2019) 
Essa grande planície, confinada entre as escarpas da Serra Geral e o oceano Atlântico, compõem-se de campos verdes, com vegetação rasteira e eventuais capões de mato. Em alguns destes capões é comum que se encontrem ninhos de animais, tais como os "garceiros " que, segundo os pescadores, são locais de reprodução e aglomeração de muitas aves. No mais, grande parte das terras é composta por campos verdes e pastagens. Dessa forma, a amplitude de visão, permitida pelo relevo baixo e contínuo, contribui para ampliar a sensação da dimensão pequena que o corpo assume no ambiente do litoral norte do Rio Grande do Sul. Para se tenha uma ideia dessa amplitude, durante a noite é possível enxergar a sinalização luminosa do parque eólico do munícipio de Osório que, em linha reta, dista em média 25 quilômetros da comunidade de pescadores da Barra. Em determinadas condições de tempo (climático) é possível enxergar o parque eólico do município de Tramandaí, que dista quase 35 quilômetros.

A amplitude de visão e a sensação do corpo que diminui, anteriormente descrita, tornase ainda maior quando me encontrava sobre uma lomba - elevações naturais quando derivam de antigas dunas, ou artificiais quando se originam da construção de canais. Em cima da lomba era possível transitar pelos campos, visualizar os meandros dos rios, as pequenas lagoas, banhados que se formam em meio à pastagem e também observar mais no horizonte os capões de mato e a serra que se coloca instransponível a oeste.

Acrescenta-se a isso, a dimensão do céu, que se abre da serra em direção ao oceano e, tanto durante o dia quanto à noite, contribui para a impressão de um horizonte sem fim. Durante as pescarias ou nos acampamentos que estive junto com os pescadores, pude presenciar as muitas maneiras que o céu transformava a terra e a água. Nas noites, diferentes tons de cores escuras diferenciavam alguns elementos, por exemplo, a água, com cores mais prateadas e os campos, capões e serra com uma coloração mais escura, por vezes quase preta. No dia, é imprescindível destacar a aurora e o entardecer. 0 nascer do sol, sempre ao leste,

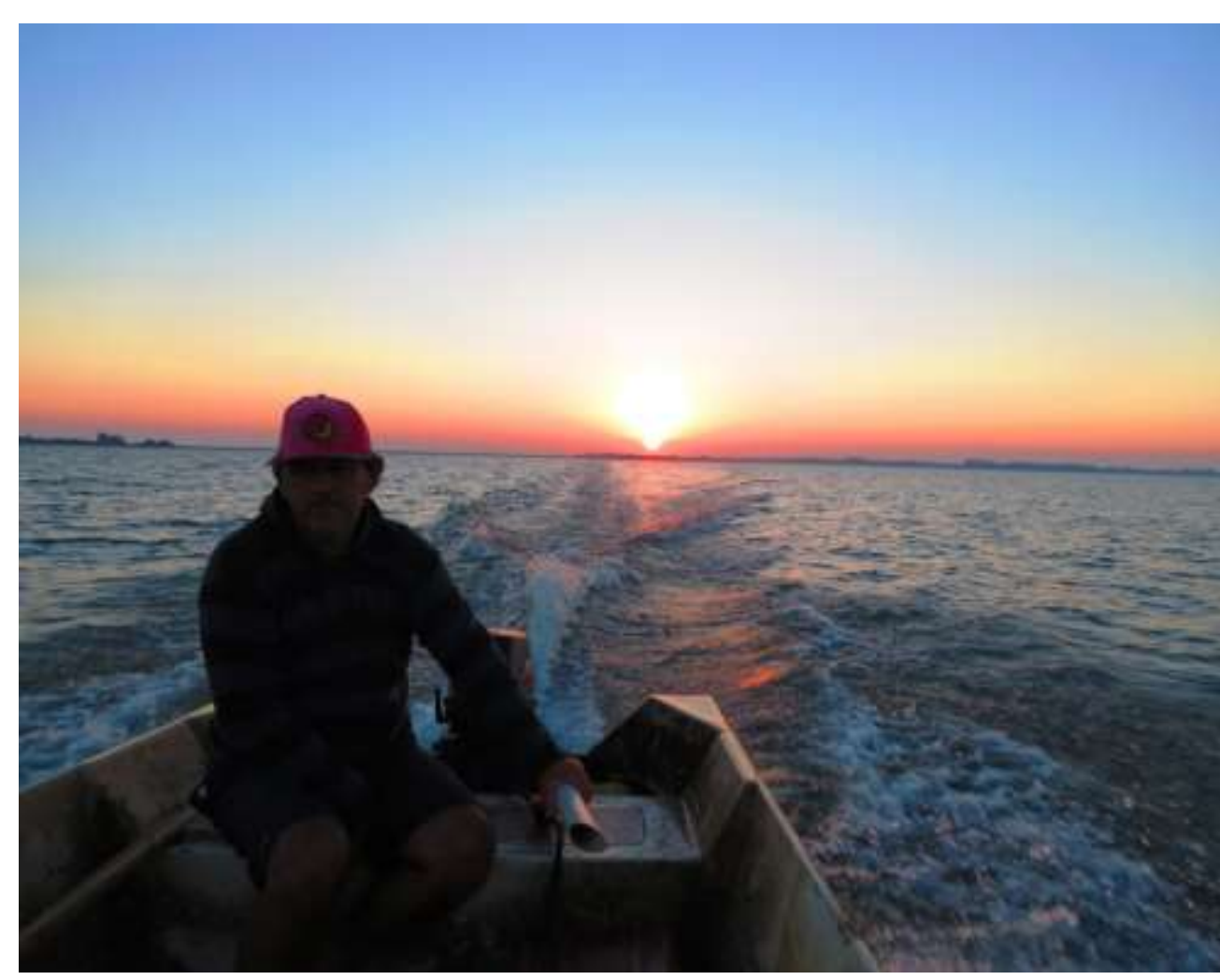

quase sempre se
revela algo muito
intenso, pois as
cores, de tons
avermelhados,
lembram o fogo e na
medida em que o sol
segue seu caminho,
vai se tornando
amarelado. Já os
finais de tarde
quase sempre
despertam r um
bucólico, o sol desce
lentamente a oeste,
se pondo atrás da
serra e deixando
uma marca
alaranjada no
horizonter ratimento

Figura 3. Nascer do sol na lagoa da Pinguela (foto do autor, 02/2015) 


\section{Navegar através dos rios}

Nesse ambiente, onde a água tem fundamental importância para a vida, os pescadores indicam que, apesar dos inúmeros rios que irrigam as lagoas da região, dois são particularmente importantes: o rio da Barra e o rio de Baixo.

0 rio da Barra é o curso hídrico que passa pela comunidade e organiza o os caminhos e direções para a navegação a partir da comunidade. Por exemplo, quando se navega a favor da correnteza (norte-sul) se desce o rio e, quando se navega contra a correnteza (sul-norte), o pescador indica que se sobe o rio. Além de organizar os caminhos e direções, o rio da Barra marca o início e fim da navegação para os pescadores da Barra do João Pedro, pois é o único curso d'água que se encontra diretamente com a comunidade. Portanto, é a partir deste rio que os pescadores navegam para outros lugares, sejam rios, lagoas ou banhados da região.

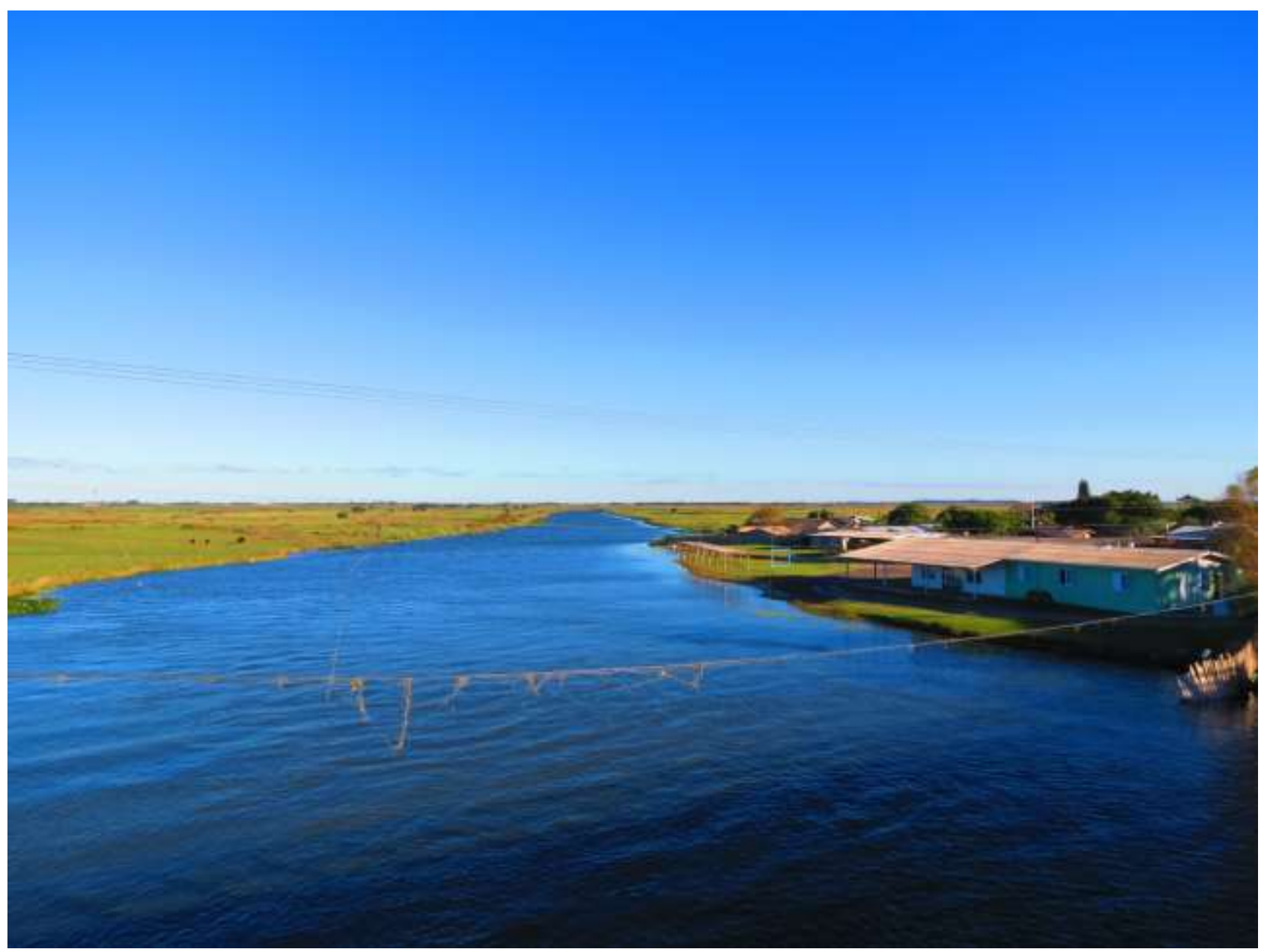

Figura 4. Rio da Barra a partir da ponte para o sul (foto do autor, 07/2019)

Seu curso em meandros inicia, conforme a correnteza, ao norte na lagoa dos Quadros e termina ao sul na lagoa das Malvas, totalizando seis quilômetros de extensão. Nas muitas curvas do rio a vegetação aquática se aglomera em alguns barrancos, pressionadas pela correnteza. Em outros lugares, formam-se pequenas praias de areia, onde o curso do rio é mais raso. Entretanto, segundo os pescadores, quase toda a extensão do rio é profunda e, em algumas curvas, formam-se os "poços", que são locais ainda mais profundos em virtude da força que a 
água exerce sobre o leito do rio. As histórias contadas sobre esses poços são sempre de grandes pescarias, principalmente quando ainda era permitida a pesca do bagre - espécie que costuma permanecer nesses locais. Depois de certo tempo trabalhando com os pescadores, comecei a identificar os poços ao longo do rio, já que só é possível identifica-los a partir de algumas características específicas, tais como, a mudança na força da correnteza e o aspecto "espelhado" que a água assume nesses locais.

Na medida em que se desce o rio - segue-se o fluxo da correnteza para o sul - é possível observar parte de sua história de vida. Os diversos pequenos canais e sangas que desaguam no rio da Barra demonstram que seu caminho mudou ao longo do tempo. Essa história visível unese aos relatos dos pescadores sobre como o rio mudou, abriu novos caminhos, ou como uma enchente forçou a água para abrir barrancos. Os rios "velhos", como denominam os pescadores, são parte da história visível dos antigos caminhos da água no rio da Barra e nos demais cursos d'água no ambiente litorâneo.

0 rio de Baixo, segundo rio destacado, fica a sudoeste da comunidade, distando aproximadamente nove quilômetros da mesma, quando realizado o caminho através da água. Seu curso inicia na lagoa das Malvas e termina na lagoa do Passo, possuindo ao todo nove quilômetros de extensão. No rio de Baixo os pescadores costumam realizar muitas pescarias, principalmente em virtude de seu isolamento, pois não existem vias de acesso para veículos terrestres, sendo cercado por propriedades rurais. Esse isolamento e a pouca agência humana consequente, segundo os pescadores, torna o rio de Baixo um lugar relevante para a pesca, principalmente pela concentração de peixes e banhados que se formam nas proximidades.

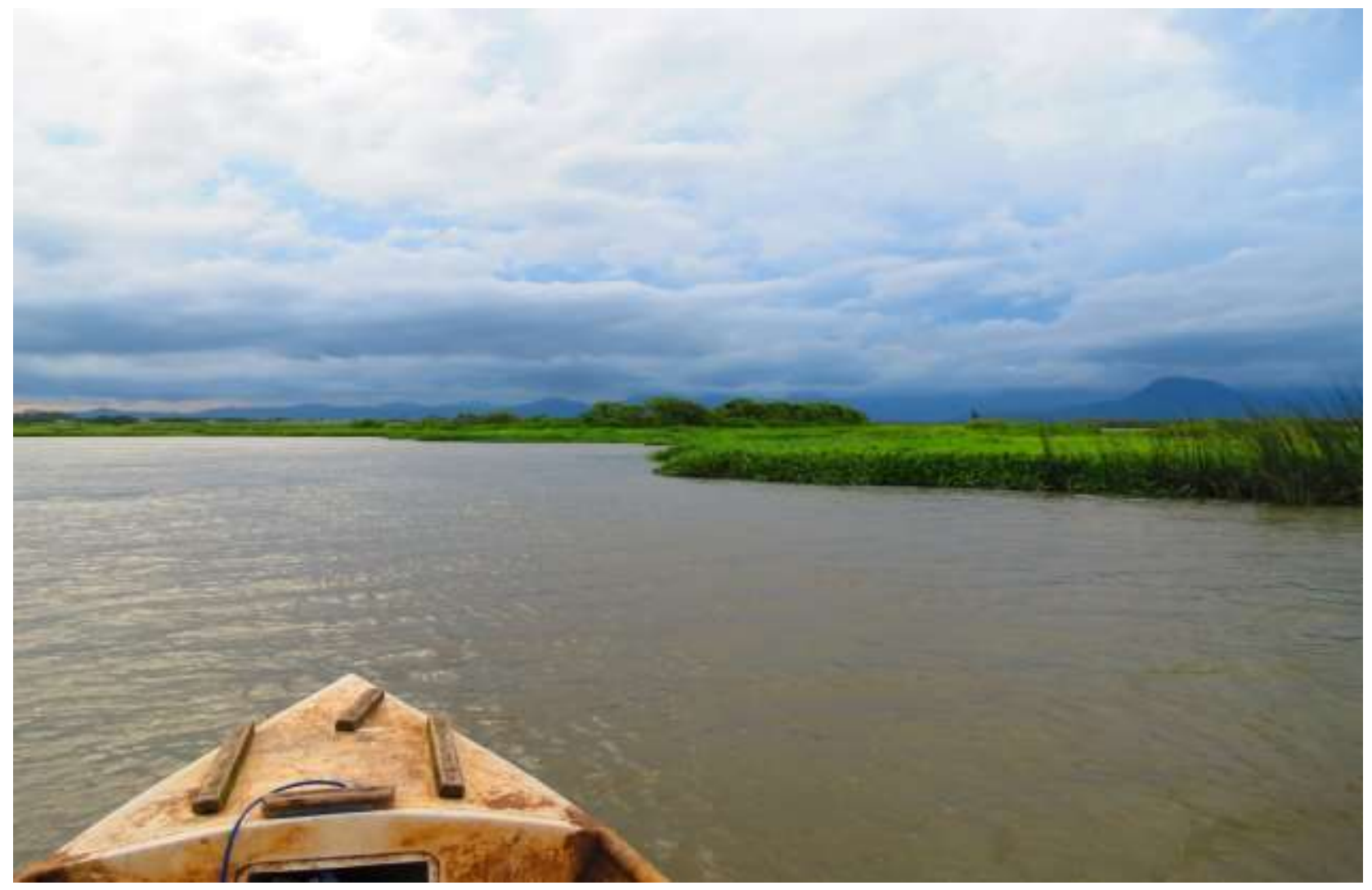

Figura 5. Navegando no rio de Baixo, próximo a ilhota (capão de mato ao fundo). (foto do autor, 02/2017) 
O isolamento do rio de Baixo da agência humana, anteriormente descrito, é ainda mais perceptível quando se observa os fenômenos que se manifestam em suas margens. Bandos de pássaros em meio à vegetação aquática, rebanhos de capivaras (Hydrochoerus hydrochaeris) e ratões do banhado (Myocastor coypus) nas lombas próximas aos banhados e rios, jacarés (Caiman latirostris) se expondo ao sol e juncais e aguapés ao longo das margens e sangas. Toda essa vida relacionada às águas brota e fervilha na região do rio de Baixo. Os pescadores empolgam-se, contam histórias, me chamam aos gritos para mostrar algum desses animais, relatam hábitos e o modo como estes animais vivem e se relacionam com o ambiente. Nessas situações, muitas vezes pedem que eu fotografe, registre um pequeno pedaço da história do lugar, de acontecimentos que se encontram misturados, articulados em um ambiente que se transforma em ciclos temporais pouco ajustados a um calendário de datas fixas.

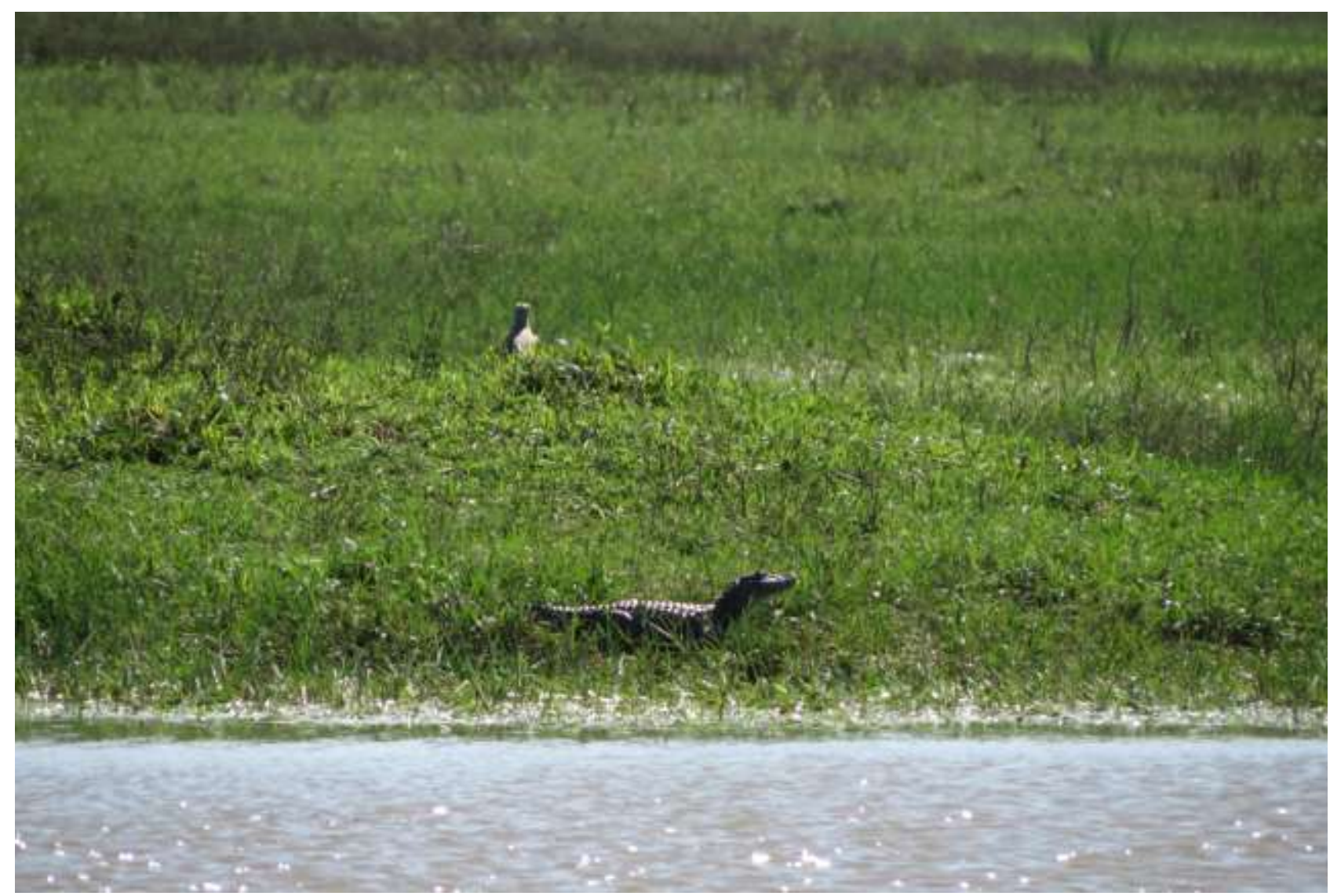

Figura 6. Jacaré no rio de Baixo (foto do autor, 10/2013)

Das vezes que naveguei ou acampei com os pescadores no rio de Baixo, fiquei impressionado com todos esses fenômenos e, mesmo no presente, esse sentimento segue se renovando sempre. 0 barulho dos pássaros, principalmente da tarrã (Chauna torquata), emitindo um som particular que coloca em alerta todos os animais próximos. Os pescadores dizem que a tarrã é o "alerta do campo" juntamente com o quero-quero (Vanellus chilensis). É comum que próximos a eles muitos outros animais permaneçam, para que possam saber da aproximação de ameaças. No mais, a diversidade de aves no rio de Baixo também é apontado como um sinal do isolamento do lugar da ação humana. Os próprios pescadores destacam que grande parte dos "garceiros" se encontram justamente na região deste rio, proporcionando uma mistura de cantos, cores e movimentos. 


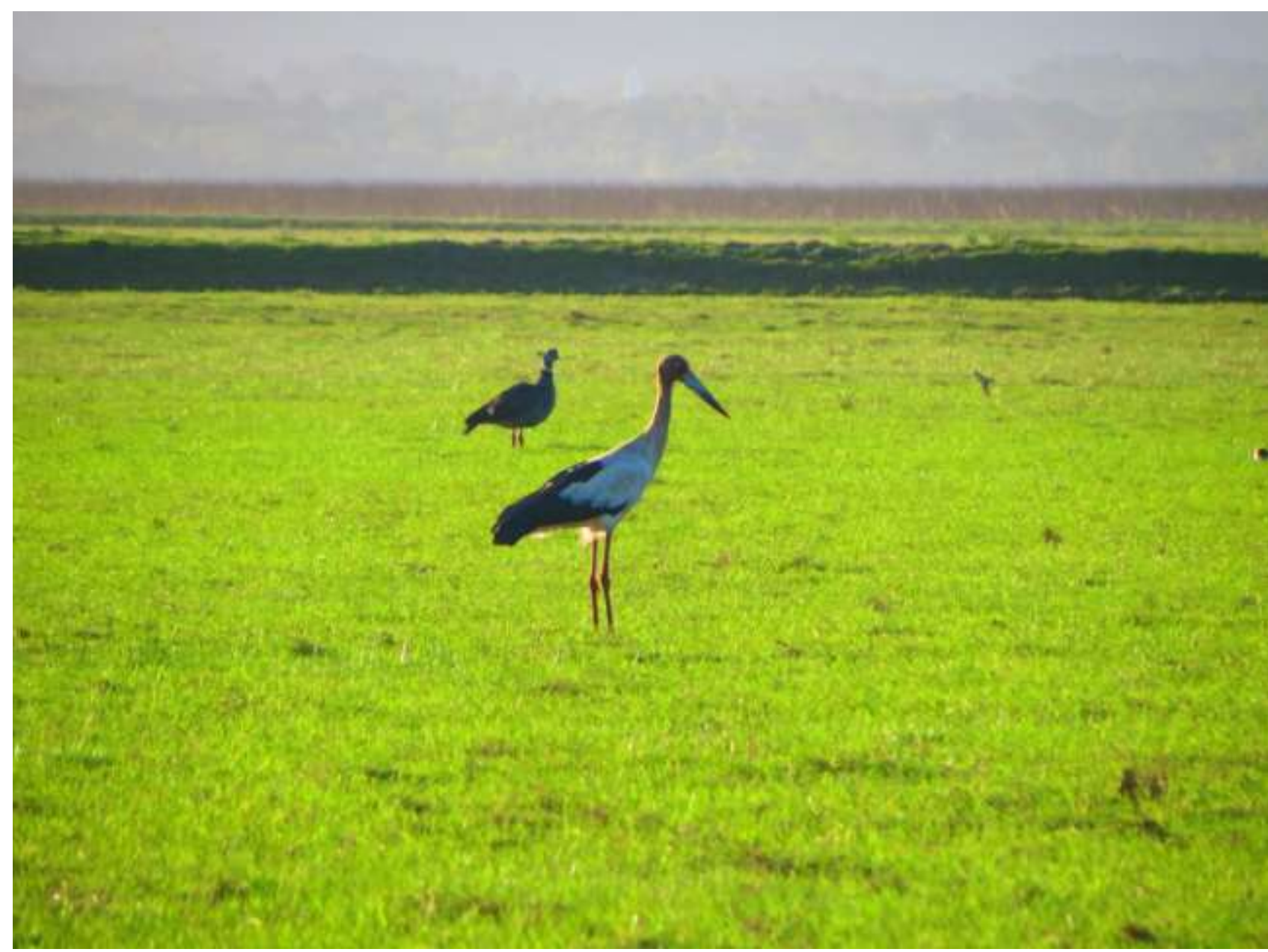

Figura 7. Em primeiro plano o João Grande (Ciconia maguari) e ao fundo a tarrã. No horizonte é possível observar os juncais que margeiam a lagoa das Malvas (foto do autor, 09/2019)

\section{Navegar através das lagoas e banhados}

Das incontáveis lagoas que fazem parte desse ambiente costeiro, algumas merecem destaque, não apenas pelo seu tamanho, mas por suas histórias, piscosidade e pela frequência de deslocamentos nelas realizadas. A lagoa dos Quadros, a maior e mais frequentada pelos pescadores, se localiza ao norte da Barra e dista, aproximadamente, um quilômetro, se deslocando através do rio da Barra. Entre as margens sul e norte, a lagoa possui mais de 14 quilômetros de extensão, sendo o seu final o limite da área de pesca.

Nas lagoas é possível compreender ainda mais a importância do conhecimento dos pescadores sobre a navegação e os fenômenos atmosféricos - "tempo", no termo local. A incidência do vento e as frequentes mudanças do tempo exigem dos pescadores a habilidade de lidar com diversas situações de navegação, conhecer os caminhos, saber se posicionar na embarcação, etc. A lagoa dos Quadros, é um dos lugares nos quais mais se verifica essas instabilidades do tempo e a necessidade do conhecimento. Navegando com os pescadores, me deparei com duas situações distintas. Na primeira, enfrentei uma tempestade ou, no termo local, uma "viração". Havíamos cruzado quase toda a extensão da lagoa dos Quadros. O pescador estava revistando suas redes quando, de repente, olhou para o sul - de onde costumam vir às virações - e pediu que eu me posicionasse na embarcação para partirmos de volta para a 
comunidade. No meio do caminho, encontramos a tempestade. 0 vento forçava a embarcação e agia sobre a superfície da água, formando ondas que alagavam parte da proa. 0 cenário era assustador, ainda mais para alguém inexperiente nas práticas pesqueiras.

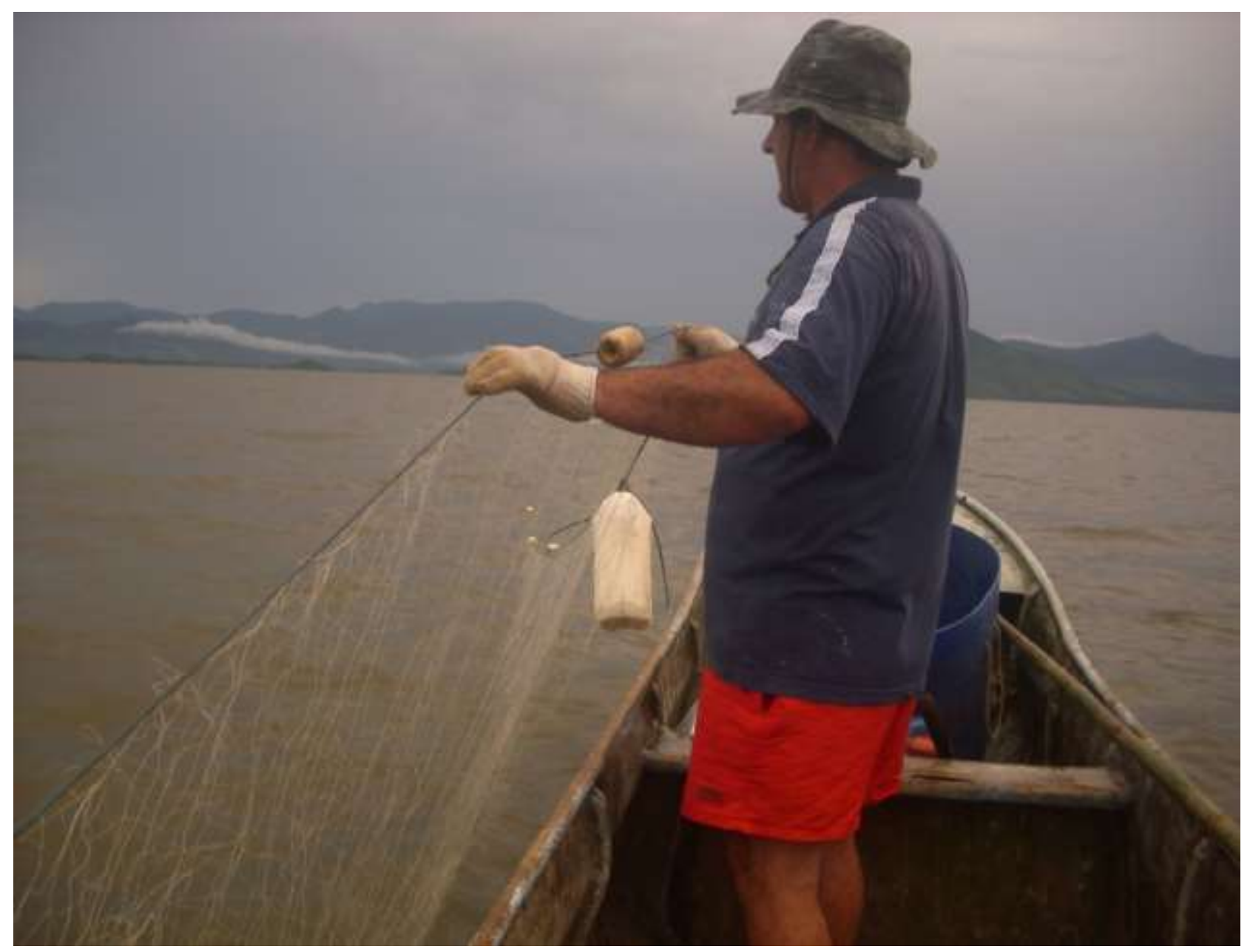

Figura 8. Pescador revisando as redes e observando uma mudança no tempo, lagoa dos Quadros (foto do autor, 02/2011).

A outra situação com a qual me deparei é a calmaria. Mais rara nas grandes lagoas, em virtude dos ventos frequentes que sopram na planície costeira, a calmaria proporciona uma experiência de difícil tradução em narrativa, principalmente pela composição de cores e lugares que se combinam na atmosfera. A água se torna um grande espelho, refletindo boa parte do céu e da serra que se projeta a oeste. Em um início de manhã ou um final de tarde, há uma combinação de cores que são refletidas pela água calma e quase sem movimento da lagoa. Apenas o movimento e o barulho da embarcação quebram a calmaria que se estabelece no lugar.

As duas situações, viração e calmaria, são características das lagoas, porém, se potencializam em virtude de algumas características do lugar. Por exemplo, no caso da lagoa dos Quadros, seu tamanho grande e a ausência de revessas , a torna mais suscetível aos ventos frequentes do litoral. 0 mesmo ocorre nas outras lagoas, porém, em menores proporções, já que possuem dimensões mais reduzidas. 


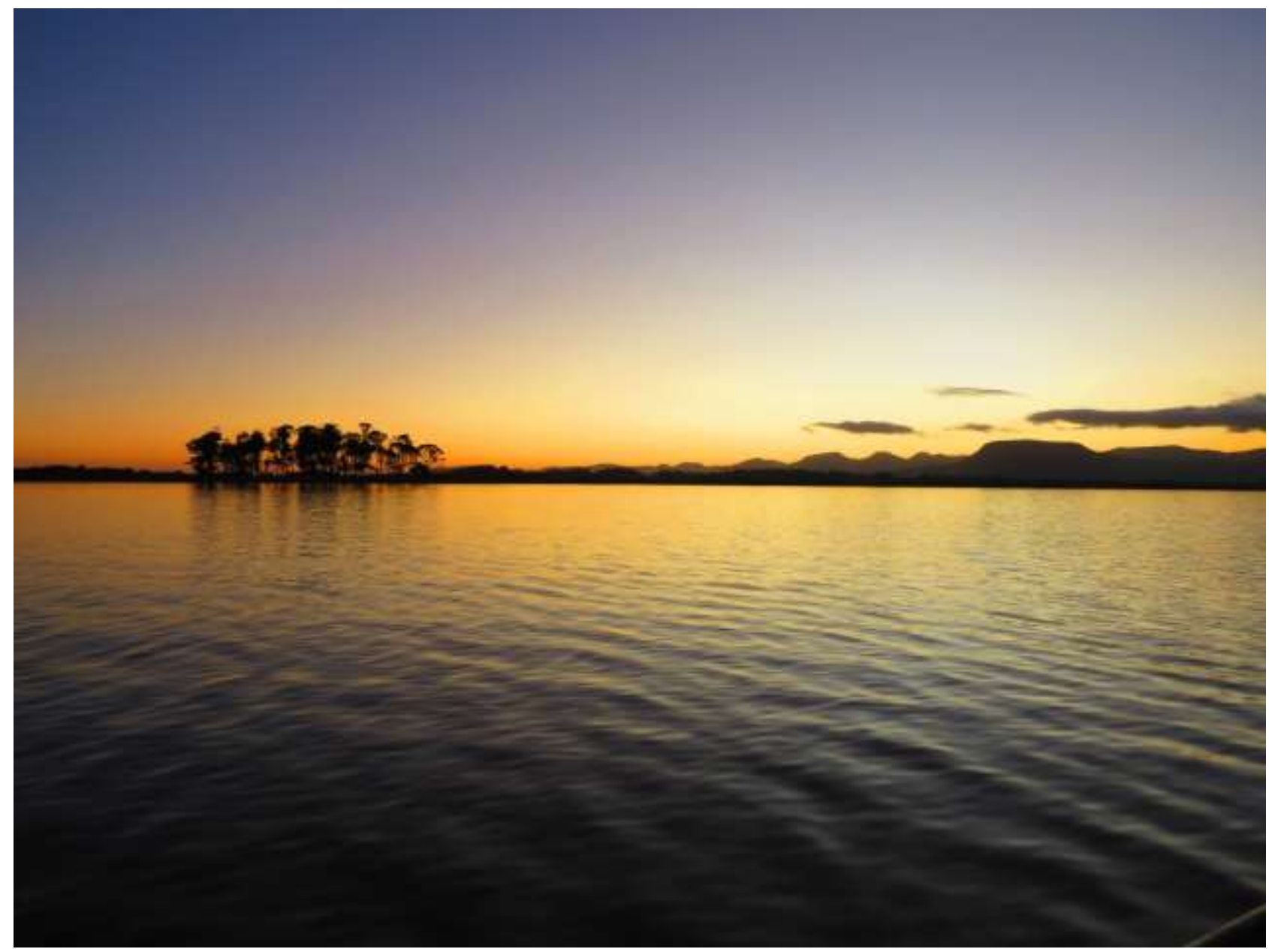

Figura 9. Um final de tarde com calmaria na lagoa dos Quadros (foto do autor, 02/2020).

Ao sul da comunidade, mais especificamente no final do curso do rio da Barra localizamse as lagoas "de baixo" - indicativo de que se deve descer o rio para chegar nelas. Dentre essas lagoas, as maiores encontram-se ligadas, de modo que, uma vez nelas, é possível se deslocar sem maiores obstáculos. A lagoa das Malvas, Palmital e Pinguela formam esse conjunto que, unidas, se tornam um importante lugar de pesca ao Sul da Barra. Contudo, mesmo juntas, não alcançam a mesma dimensão da lagoa dos Quadros. Por último, também se destaca a lagoa do Passo (Passo da lagoa), que se encontra no final do rio de Baixo, apontada como um lugar importante para a pesca de espinhel.

Além disso, inúmeras lagoas pequenas - as "lagoinhas", no termo local - se localizam justamente nas proximidades dessas lagoas maiores que estão ao sul. 0 deslocamento até essa região é feito através do rio da Barra e da lagoa das Malvas. Até o final desse encadeamento de lagoas, o pescador pode se deslocar mais de 20 quilômetros, em virtude das curvas e do emaranhamento dos caminhos aquáticos. Esses lugares também fornecem muitos peixes e se apresentam como uma possibilidade de diversificar e manejar a área de pesca em todas suas potencialidades, não apenas como uma alternativa a escassez de peixe da lagoa dos Quadros. 


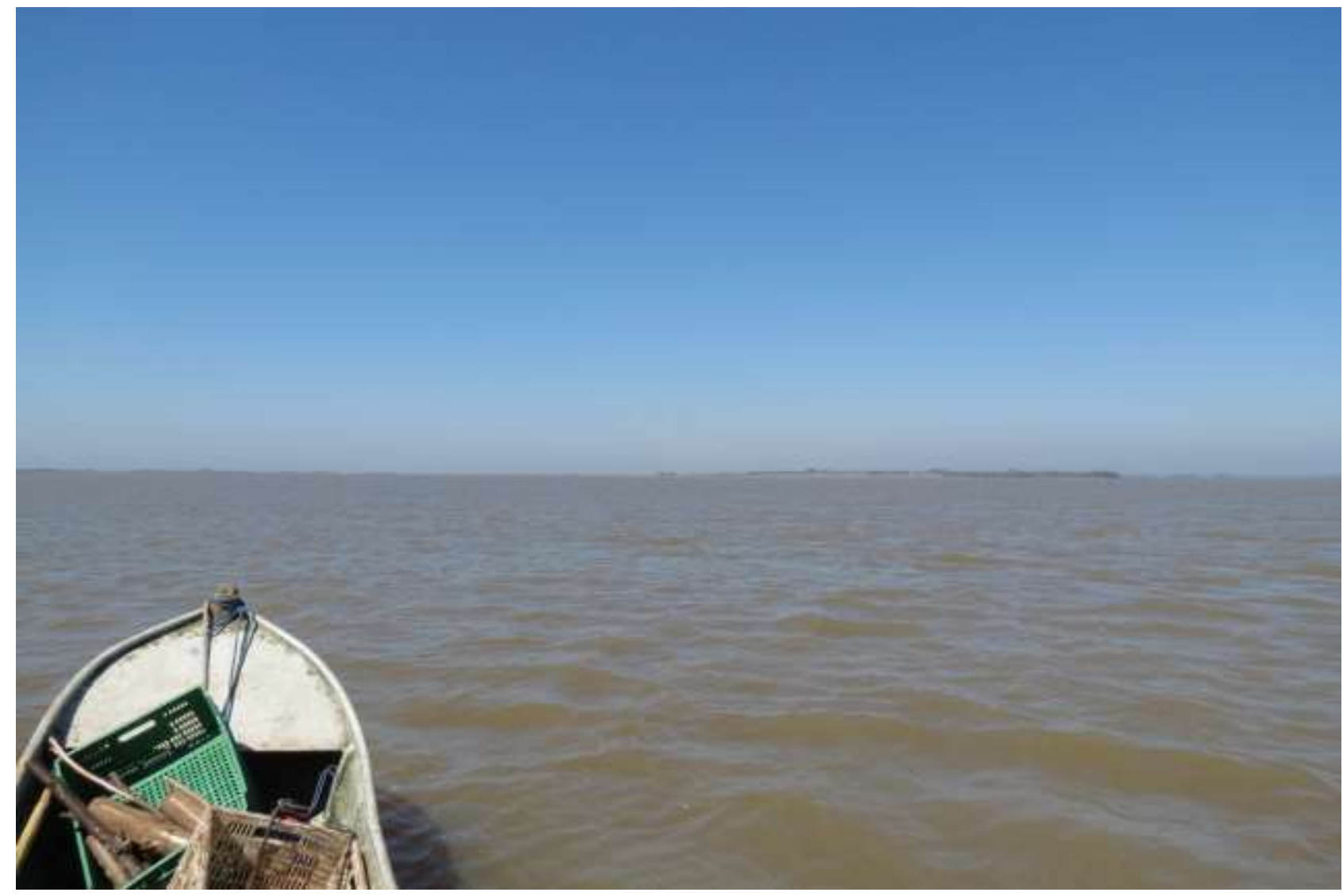

Figura 10. Navegando na lagoa das Malvas (foto do autor, 09/2013)

Esses corpos hídricos oferecem muitas alternativas para os pescadores, principalmente em diversidade de pesqueiros, refúgios e locais para acampamento. Os pescadores afirmam que as margens recortadas e irregulares dessas lagoas as tornam excelentes refúgios para o pernoite, principalmente pelos lugares que proporcionam proteção das ações do tempo, tais como o vento, o frio e a chuva. Nos caminhos trilhados até os acampamentos, a embarcação pesada - pelos mantimentos, materiais de pesca e barracas - deslocava-se lentamente através dos rios e lagoas, aumentando minha expectativa para conhecer o lugar de pouso.

No último acampamento que acompanhei os pescadores (10 e 11 de fevereiro de 2020) nos deslocamos até a lagoa do Passo, percorrendo 19 quilômetros até o lugar de pernoite. Permanecemos uma noite nesse local, pois o pescador se deslocou até a lagoa do Passo para a pesca de traíras (Hoplias sp.). Em um pequeno canal de ligação com outras lagoas menores, o pescador sugeriu que pousássemos em uma estrutura pré-existente, uma embarcação flutuante semelhante a uma casa - localmente conhecida como "chata", em virtude de seu casco plano para flutuação. Essa estrutura pertence ao fazendeiro dono das terras da região, que autorizou nossa permanência no local. 


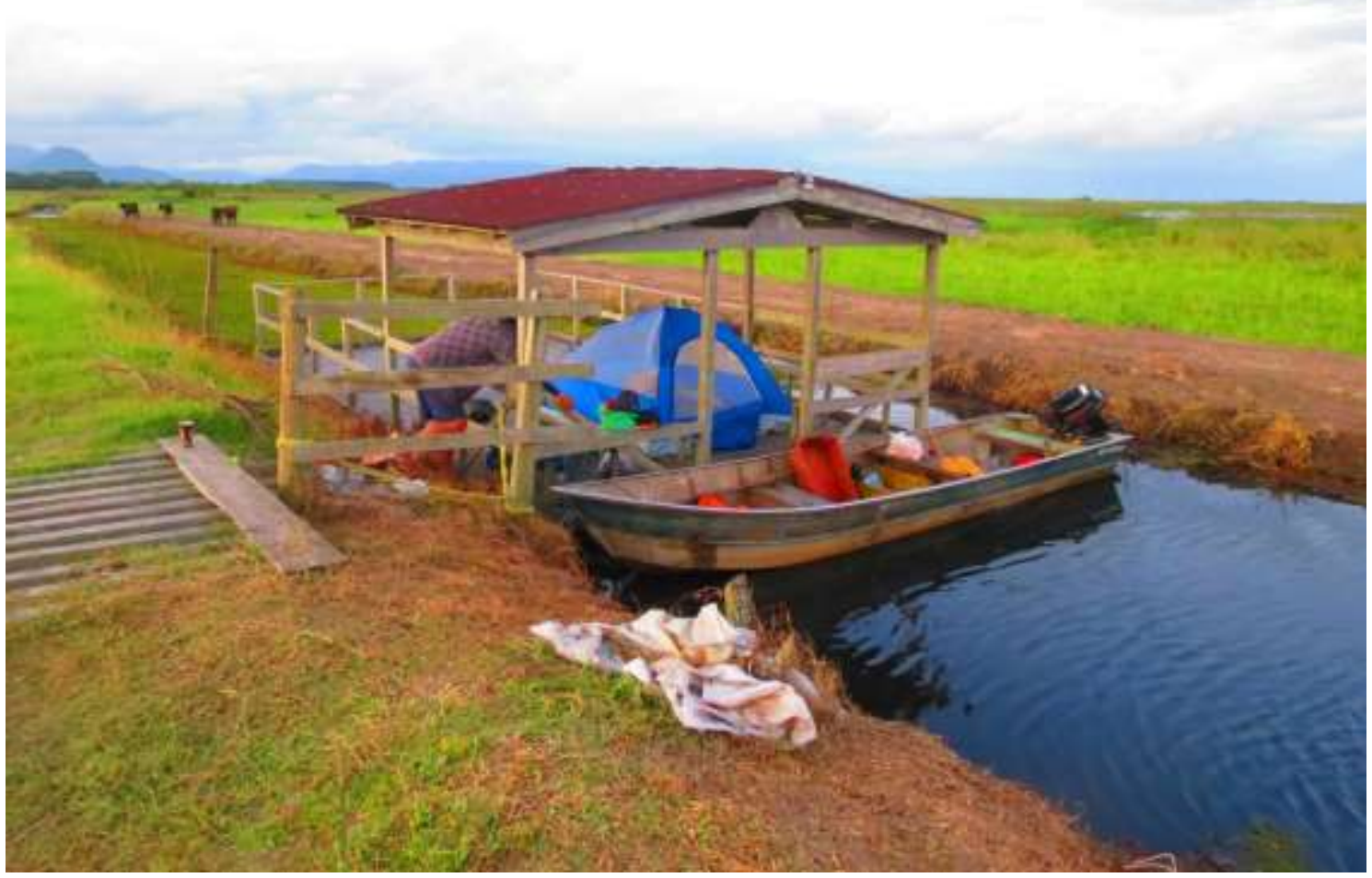

Figura 11. Acampamento na lagoa do Passo (foto do autor, 02/2020).

Na margem oeste da lagoa do Passo, onde permanecemos, misturavam-se diversos lugares. Os campos verdes na sua margem, os juncais e aguapés nas partes rasas da lagoa e as sangas que alimentam os fluxos de água. Ao longe, na margem leste, é possível ver as luzes das cidades e dos condomínios fechados que se alastram nas cercanias das lagoas, reforçando a reclamação constante dos pescadores sobre a destruição dos banhados próximos as lagoas. Durante a noite, enquanto preparávamos o jantar, o pescador pediu que eu observasse a lua cheia, que iluminava o céu, a terra e a água. Especialmente a água, pois esta refletia a luz do luar, evidenciando a diferença entre a superfície fluída da lagoa e a solidez dos campos à sua volta. Tentei de muitos modos registrar esse momento com uma fotografia, mas, infelizmente, as lentes não conseguiram captar a narrativa que apresento. 


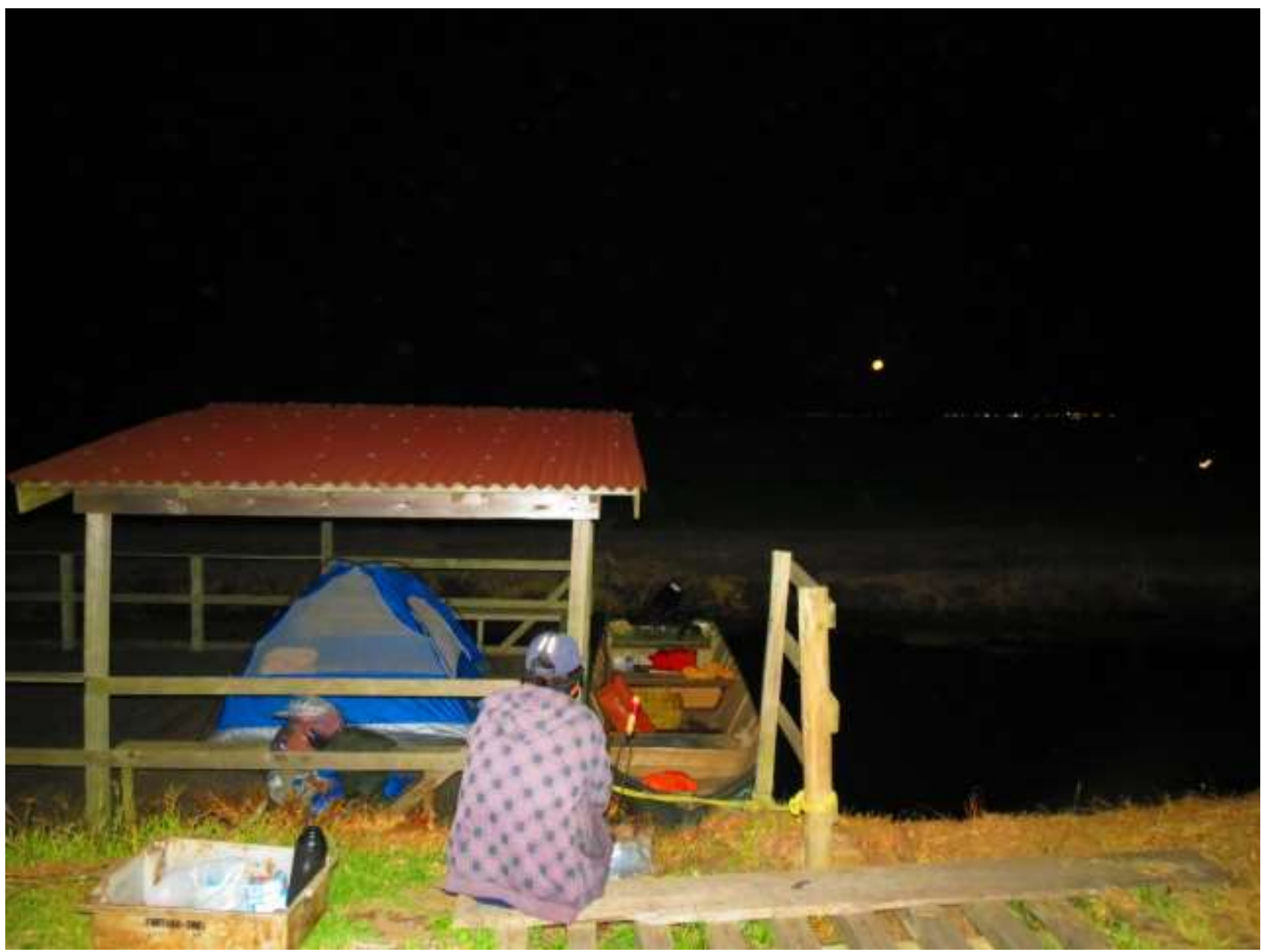

Figura 12. 0 pescador, o acampamento, as luzes dos condomínios e a lua (foto do autor, 02/2020 [com flash]).

\section{O fluxo das águas}

Nesse ambiente em constante movimento as águas também se transformam. Os ciclos sazonais de vazante e cheia alteram de modo significativo o ambiente e também transformam as percepções que temos ao observar os lugares. Os pescadores mudam suas práticas de pesca, buscam outros pesqueiros, tentam tirar o máximo proveito das condições que se oferecem e, ao mesmo tempo, buscam minimizar os impactos "negativos" que cada uma das épocas proporciona. Não se trata de uma relação verticalizada - do ambiente determinando comportamentos - mas de práticas associadas ao conhecimento de seu próprio ambiente enquanto seu lugar de vida.

A época da vazante é o momento em que o nível das águas encontra-se baixo e se estabelece um clima mais seco e ameno. As lagoas e rios são mais secos e as chuvas são mais esparsas. Esse período corresponde, de modo geral, à primavera e ao verão, quando as condições de pesca são menos agressivas, pois o vento tende a ser mais fraco e o clima ameno, facilitando o trabalho dos pescadores. A planície de campos verdes, com eventuais capões de mato, possui uma vida terrestre e alada muito diversa, composta por capivaras, ratões do banhado, inúmeras espécies de aves e as criações de gado e ovelhas das fazendas da região. 


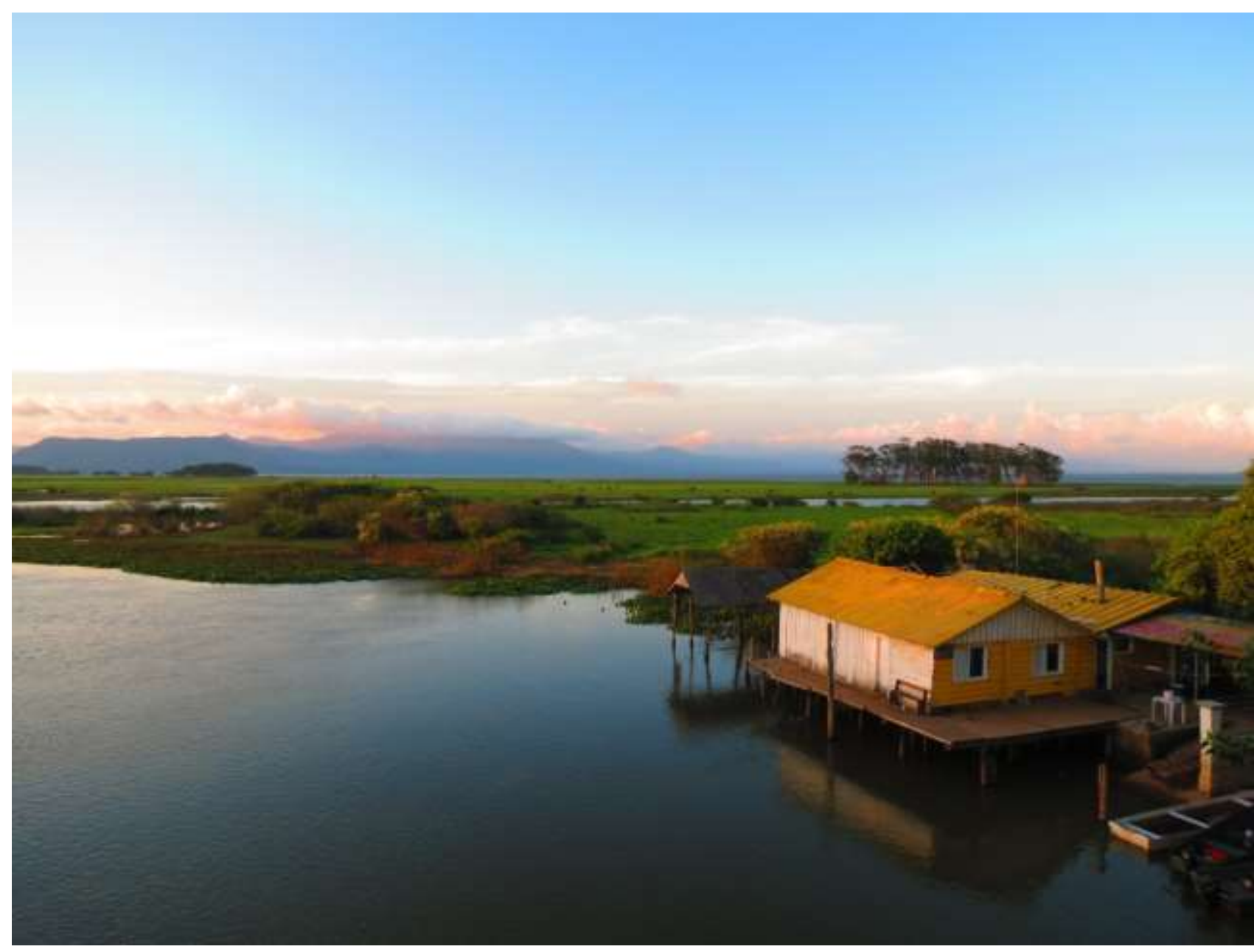

Figura 13. 0 rio da Barra, os campos e a lagoa dos Quadros ao fundo (foto do autor, 02/2016).

Esses campos contrastam com os rios sinuosos e com as lagoas que, por vezes possuem a coloração prateada ou, em dias com ventos mais fortes, um aspecto caudaloso-marrom. Os finais de tarde costumam ser muito aprazíveis, já que o clima mais ameno, aliado aos dias mais longos (característicos da primavera e do verão), possibilita aos pescadores seguir navegando e realizando suas tarefas na água com mais tranquilidade. Navegar nas grandes lagoas ou rios, principalmente no amanhecer ou no final da tarde, está entre as atividades mais prazerosas no trabalho etnográfico com os pescadores. Na medida em que revista suas redes ou coloca um espinhel, o pescador conta histórias de grandes pescarias que realizou, perigos que enfrentou e outros fenômenos que observou. Conforme o diálogo segue, eventualmente desviava o olhar, observava o sol, a água e a serra e percebia que nessa composição as historias se potencializam, dando um sentido material a todas as vivências que o pescador relatava. 


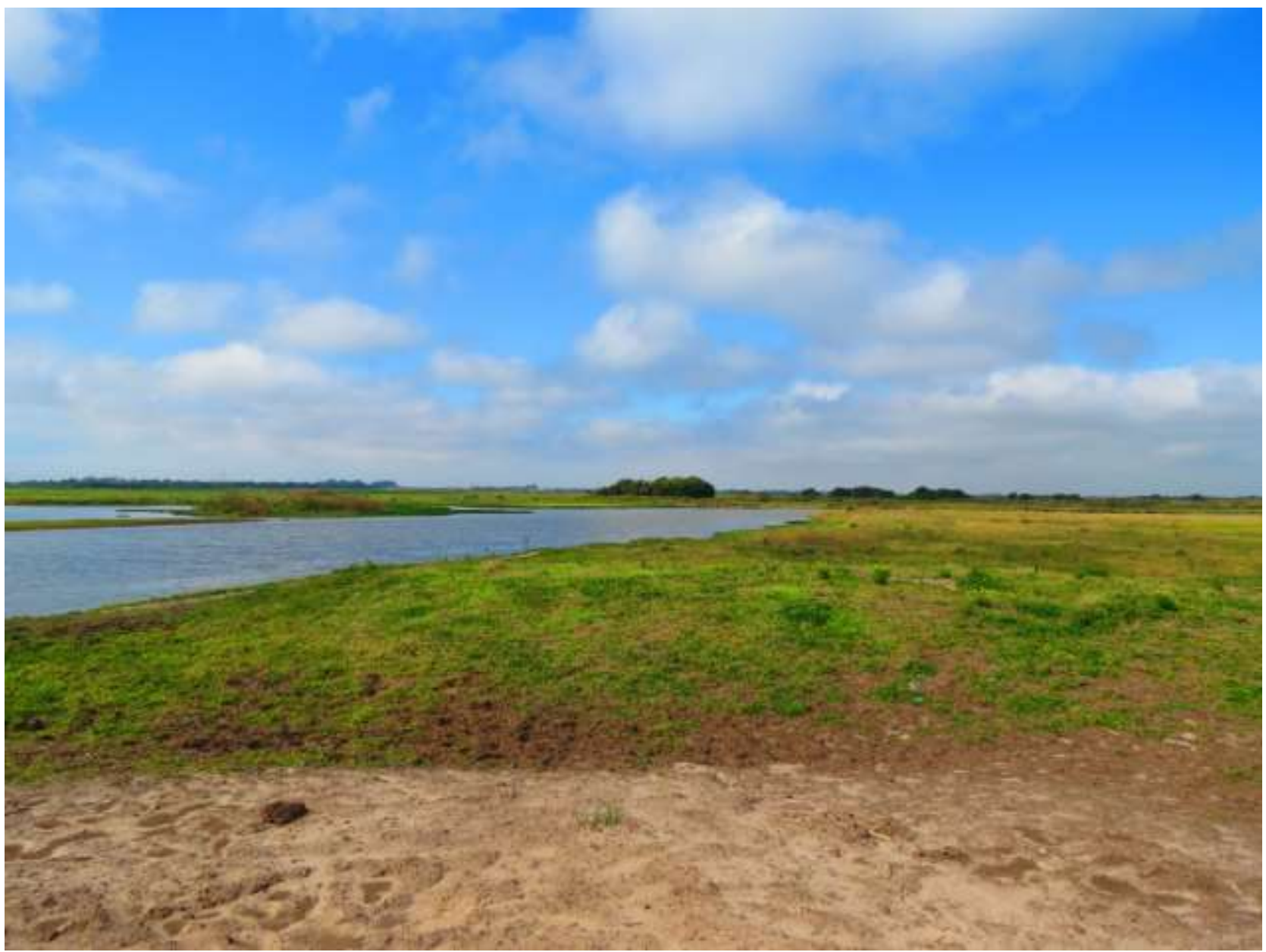

Figura 14. 0 campo e o rio da Barra, ao fundo um capão de mato. (foto do autor, 09/2019)

A época de cheia corresponde ao período das chuvas que ocorre no outono e no inverno. Há um aumento significativo do nível das águas, tanto dos rios quanto das lagoas, formando grandes banhados na região. Campos e pastagens, a partir da cheia, tornam-se campos alagados de proporções igualmente grandes, modificando o ambiente de modo significativo. Animais terrestres e alados dão lugar aos peixes e outros animais aquáticos, que passam a ocupar esses lugares para reprodução de seu modo de vida. Os pescadores afirmam que os banhados são locais importantes para a pesca, principalmente porque se trata do local de reprodução de muitas espécies, como jundiás (Rhamdia sp.) e traíras. Também apontam para a importância dos banhados como lugares de maior segurança para a navegação, principalmente pela baixa profundidade da água e menor incidência dos ventos, que costumam ser de mais intensos nessa época de cheia.

Durante o período de cheia o grande volume das águas e a intensidade dos ventos transformam o ambiente. No ano de 2015, segundo os pescadores, ocorreu uma das maiores enchentes dos últimos 20 anos. Nela pude perceber a força das águas e dos ventos sobre os campos, tomando a terra e misturando as lagoas e rios em um só corpo d'água - observe as diferenças entre a figura 13 e 15. Diante disso, a impressão que tive no momento era da ausência de controle que temos sobre os fenômenos relacionados à superfície fluída. 


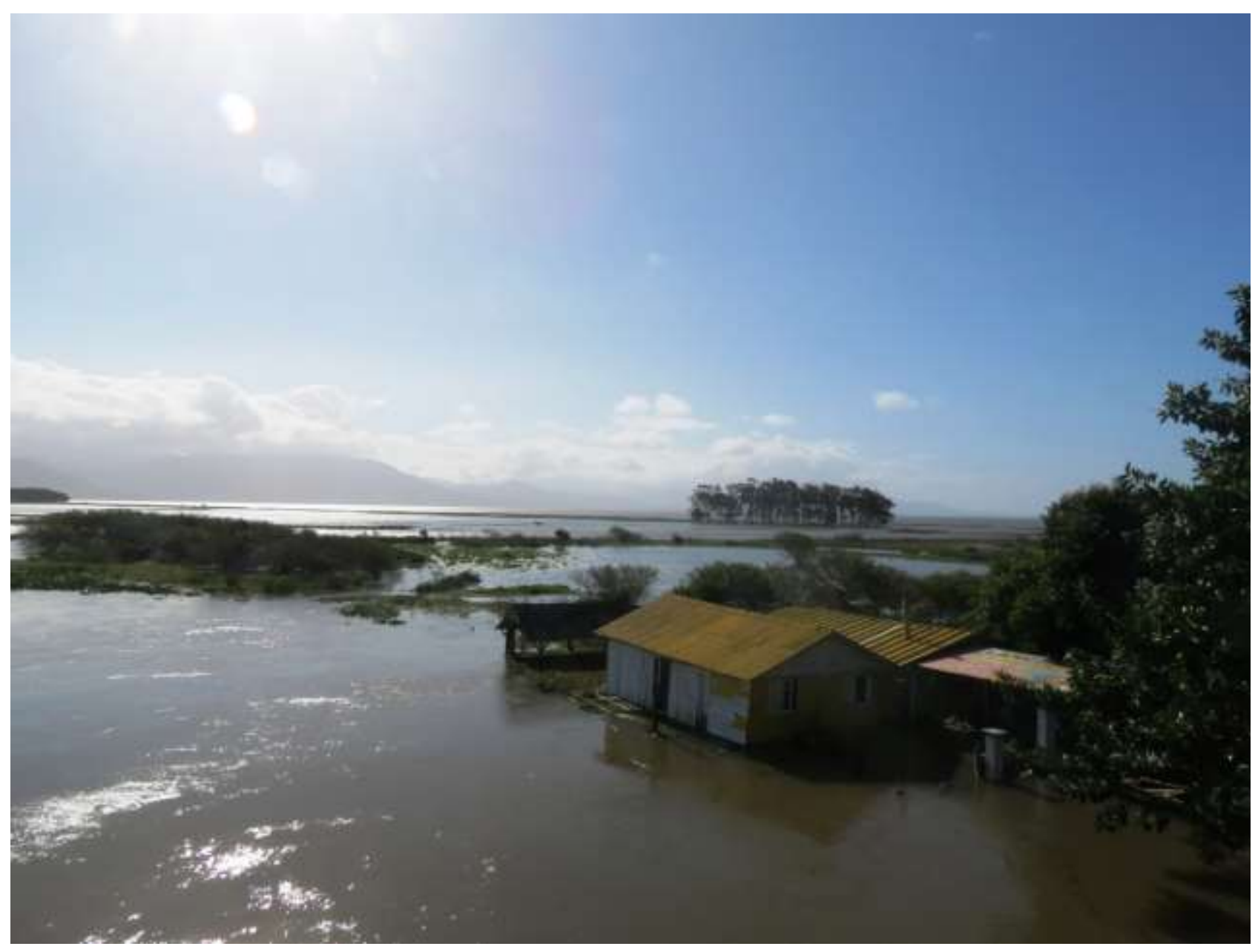

Figura 15. A enchente de 2015 a partir da ponte do rio da Barra (foto do autor, 07/2015)

A terra torna-se refém da água que se espalha conforme cresce em volume. Ao longe eram visíveis as ondas que se formam nas grandes lagoas em virtude do vento e, por consequência, entendia o porquê dos pescadores evitarem esses locais durante as cheias. 0 vento, o frio e as águas agitadas das lagoas, assim como a instabilidade atmosférica da região que se acentua, desafiam as habilidades dos pescadores e os encaminham para outras estratégias de pesca na região (SILVA, 2012; 2015)

Porém, também me deparei com outras situações em época de cheia, não tão extremas como a enchente de 2015. Os campos alagados ao sul da comunidade costumam ser muito buscados pelos pescadores, essencialmente por se tratarem de locais de grande piscosidade. Nesses banhados os jundiás e traíras buscam um refúgio para a reprodução, bem como as tainhas (Mugil sp.) que se alimentam do limo que se concentra nas águas mais paradas. 


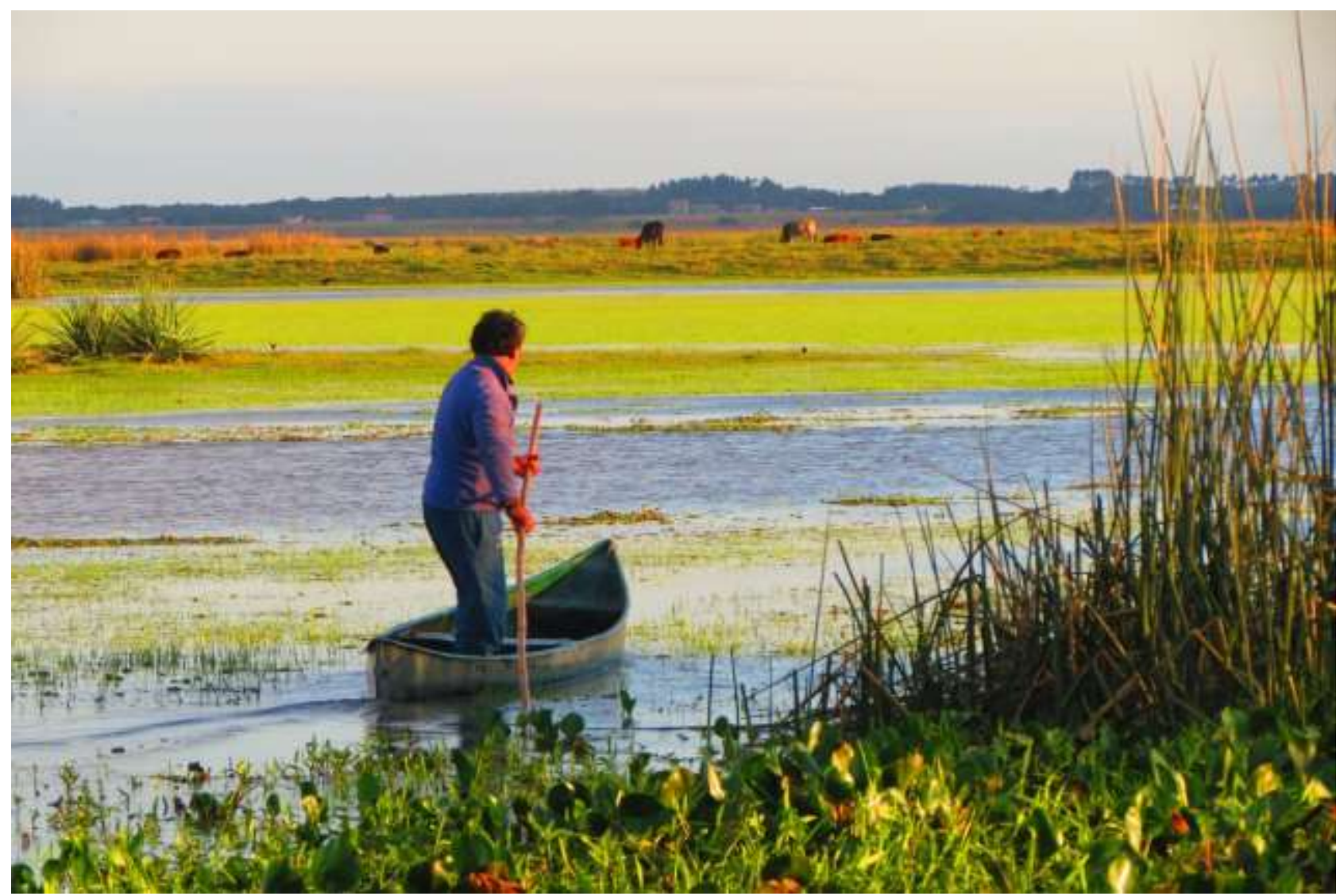

Figura 16. Pescador navegando nos banhados próximos rio da Barra (foto do autor, 07/2014).

Aos olhos do observador, águas e campos misturam-se, e essa fusão fica ainda mais evidente quando se admira o crescimento da grama boiadeira acima da superfície d'água, mesclando a superfície fluida com a sólida. Tal como na figura acima, essa fusão proporciona a impressão de uma embarcação que flutuava sobre as águas. 0 movimento silencioso sobre a lâmina d'água alia-se a atmosfera invernal do ambiente litorâneo, revelando nessa tranquilidade a mistura de cores e percepções dos campos alagados.

0 impacto desses períodos sobre a pesca é verificado, principalmente, na navegação e na utilização da área de pesca. Nas condições climáticas adversas que se estabelecem durante o período das cheias, os pescadores optam pela busca das áreas mais abrigadas, tais como os banhados e os rios, em detrimento das lagoas, que são afetadas pela força do vento e da água. Já no período de vazante, verifica-se uma ampla utilização dessa área de pesca, e os pescadores realizam grandes deslocamentos ao longo das lagoas e dos rios para pescar. De modo geral, a sazonalidade na Barra do João Pedro se vincula a este ciclo das águas e não à migração das espécies de peixes, tendo em vista que estas mantem-se, relativamente, estáveis ao longo do ano, exceto por alguns peixes marinhos que costumam entrar na água salobra entre a primavera e o verão (SILVA, 2012, 2015).

As mudanças significativas que ocorrem de uma época vazante para cheia, nos conduzem a constituir diferentes relações e percepções. Os pescadores acionam seus conhecimentos por meio de diferentes estratégias de pesca, seja pelo uso de novos materiais, ou pela busca por novos pesqueiros. Ao participar de muitas pescarias, busquei também 
observar em que medida essas transformações me impactavam, como eu as percebia e qual a melhor maneira de fazer uma narrativa dessas experiências. Navegando com os pescadores visitei lugares pouco conhecidos e vivenciei a experiência embarcada através de um olhar arqueológico, pensando o mundo a partir de sua materialidade.

Com isso, para concluir essa descrição parcial de minhas percepções do ambiente, destaco a importante mediação dos pescadores da Barra do João Pedro. Nestes dez anos de pesquisa na comunidade me aproximei das pessoas, demais seres e da paisagem da região e, ao longo disso, aprendi e conheci os lugares a partir de uma perspectiva local.

\section{Considerações finais}

A etnografia arqueológica, que venho conduzindo junto aos pescadores, possibilitou compreender como os mesmos se relacionam com sua materialidade e paisagens. Ao mesmo tempo, experimentei essas práticas e percebi de diversas maneiras os fenômenos que observava.

Toda a narrativa aqui apresentada faz parte de uma trajetória de pesquisa. Nesse percurso procurei demonstrar que inúmeras vezes nos confrontamos com lugares distintos, com histórias contadas e certos sentimentos que se originam ao observar esses fenômenos. Deslizando sobre as águas dos rios, das lagoas e dos banhados busquei apresentar, tal como destacado na epígrafe inicial, como essa aura do ambiente litorâneo me afetou e influenciou na condução de minhas observações e na construção da narrativa. Foi exatamente essa trama do lugar e do tempo que busquei descrever nesse relato sobre o ambiente, como uma tentativa de aproximar o leitor das experiências vivenciadas junto aos lugares com os pescadores.

Ao buscar em Roquette-Pinto (1962[1906]) a inspiração e o modelo de narrativa, compreendi a importância de deixar as percepções fluírem por meio escrita. Descrever os lugares, os materiais, os gestos das pessoas e os demais seres auxiliaram a construir a necessária dimensão do sensível ao longo do trabalho etnográfico. A contribuição de RoquettePinto segue justamente nessa trama peculiar entre "espaço e tempo" que persegui ao longo de minha narrativa.

Com isso, penso que essa tessitura entre percepções, inspirações e mediações, constitui parte fundamental dos trabalhos de campo e, portanto, deve fazer parte de nossos textos como uma expressão do aprendizado que obtivemos junto às comunidades e ao mundo. Trata-se de descrever a "aura" da qual momentaneamente fizemos parte.

\section{Referencias}

Benjamin, W. (2013). A obra de arte na era de sua reprodutibilidade técnica. Porto Alegre: L\&PM editores.

González-Ruibal, A. (2006). The past is tomorrow. Towards na archaeology of the vanishing present. Norwegian Archaeological Review, v. 39 (2), p.110-125.

González-Ruibal, A. (2009) De la etnoarqueología a la arqueología del presente. In: Salazar, J.; Domingo, I.; Askarrága, J.; Bonet, H. (Coord.). Mundos tribales: una visión etnoarqueológica. Valencia: Museo de Prehistoria, p. 16-27.

González-Ruibal, A. (2014). An archaeology of Resistance: materiality and time in na African borderland. Plymouth: Rowman \& Littlefield. 
Ingold, T. (2000). The Perception of the Environment: Essays on Livelihood, Dwelling and Skill. London: Routledge.

Ingold, T.(2012). Trazendo as coisas de volta à vida: Emaranhados criativos num mundo de materiais. Horizontes Antropológicos, ano 18 (37), p. 25-44.

Ingold, T. (2013a). Los materiales contra la materialidade. Papeles de trabajo, v.7 (11), p.19-39.

Ingold, T. (2013b). Repensando o animado, reanimando o pensamento. Espaço Ameríndio, v.7 (2), p.10-25.

Ingold, T. (2014). That's enough about ethnography!. HAU: Journal of Ethnographic Theory, v.4 (1), p. 383-395.

Ingold, T.(2015). Estar vivo: ensaios sobre movimento, conhecimento e descrição. Petrópolis: Editora Vozes.

Roquette-Pinto, E. (1962[1906]). Relatório de excursão ao litoral e à região das lagoas do Rio Grande do Sul. Porto Alegre: UFRGS.

Schossler, J. (2010) “As nossas praias": os primórdios da vilegiatura marítima no Rio Grande do Sul (1900 - 1950) (Tesís de maestría). Programa de Pós Graduação em História, Pontifícia Universidade Católica do Rio Grande do Sul, Porto Alegre.

Silva, L. (2012). Pescadores da Barra do João Pedro, um estudo etnoarqueológico (Tesís de maestría). - Programa de Pós-Graduação em História, Pontifícia Universidade Católica do Rio Grande do Sul, Porto Alegre.

Silva, L. (2015). Com vento a lagoa vira mar: uma etnoarqueologia da pesca no litoral norte do RS. Boletim do Museu Paraense Emílio Goeldi. Ciências Humanas, v. 10 (2), p. 537-547.

Silva, L. (2017). (Re) visitando as pessoas e as coisas: A Etnoarqueologia enquanto uma Arqueologia do Presente. Revista de Arqueologia, v. 30 (1), p. 175-185.

Silva, L. (2018). Os materiais de pesca fluindo. Uma Arqueologia com os pés na água (Tesís de doctorado). Museu Nacional, Universidade Federal do Rio de Janeiro, Rio de Janeiro.

Silva, L. (2019). A fluidez das relações materiais. Uma arqueologia com os pés na água. Revista de Arqueologia, v.32 (1) p. 108-128.

Tilley, C. (1994) A phenomenology of landscape. Oxford: BERG.

Tilley, C. (2004) The materiality of Stone. Oxford: BERG.

Wagner, G. (2009). Sambaquis da barreira da Itapeva uma perspectiva geoarqueológica (Tesís doctoral). Programa de Pós-Graduação em História, Pontifícia Universidade Católica do Rio 
Grande do Sul, Porto Alegre. 